\title{
Preface: The role and influence of biblical values on social change
}

\author{
Author: \\ Francois P. Viljoen ${ }^{1}$ \\ Affiliation: \\ ${ }^{1}$ Faculty of Theology, \\ North-West University, \\ Potchefstroom Campus, \\ South Africa \\ Email: \\ viljoen.francois@nwu.ac.za \\ How to cite this article: \\ Viljoen, F.P., 2014, 'Preface: \\ The role and influence \\ of biblical values on social \\ change', In die Skriflig 48(1), \\ Art. \#1901, 2 pages. \\ http://dx.doi.org/10.4102/ \\ ids.v48i1.1901

\section{Copyright: \\ (c) 2014. The Authors. \\ Licensee: AOSIS \\ OpenJournals. This \\ work is licensed under \\ the Creative Commons \\ Attribution License.}

A conference with the theme 'The role and influence of biblical values on social change' was held at the Faculty of Theology of the NWU in Potchefstroom in August 2013, and was hosted by the Unit for Reformed Theology and the Development of the South African Society. Several international scholars were invited to contribute along with South African scholars on the role of the Bible for the renewal of society. Seventeen articles were presented followed by thorough discussions providing bibliological, ecclesiastical, ethical, apologetic, homiletic and pastoral perspectives on moral issues. The intention was to sound a prophetic voice on empowerment and sustainable development within society. A selection of these articles were offered for publication in this edition of In die Skriflig/In Luce Verbi. These articles provide bibliological, apologetic, and pastoral perspectives on the theme of the conference.

\section{Bibliological perspectives are provided both from the Old and the New Testament:}

- Dr Antje Labahn presented her article on wealthy women in antiquity and compared the capable woman of Proverbs 31:10-31 with Mibtahiah from Elephantine. She indicates how these conceptions of wealthy female characters describe their potential to positively influence their societies.

- Dr Dexter E. Callender's contribution also comes from the Old Testament. He investigates the passage from Ezekiel 20:25: 'I gave them laws that were not good' and provides a biblical model of complex subjectivity and the prospects of multi-ethnic contextual reading. He addresses the problem of multicultural multi-ethnic contextual Bible reading. He argues for grounding multigroup reading strategies that seeks to bridge contemporary discourse with the language of the biblical text.

- From the New Testament Prof. Dr Francois P. Viljoen contributed on external cultic tradition and internal ethical purity according to Matthew 15. In Matthew 15:1-20 Jesus responds to the accusation made by the Pharisees and the scribes that his disciples do not observe the tradition of hand-washing. It seems that Matthew uses this story to define and maintain the identity and values of his community over and against that of the Pharisees and their successors. Devices are identified that Matthew uses to define the identity and required morality for his community. Such devices demonstrate how a community's values can influence the identity and ethics of a society.

- Also providing a New Testament perspective, Prof. Dr Jan G. van der Watt read his article on the possible use of mimesis in 1 John. He gives an overview of the use of mimesis in ancient times. References in 1 John to believers that must be or act like Jesus are identified and interpreted in the light of ancient mimesis.

- Dr Michael Labahn's contribution comes from the book of Revelation as an early Christian 'search for meaning' in critical conversation with its Jewish heritage and Hellenistic Roman society. As a piece of subversive narrative, Revelation constructs a meaningful narrative world divided in good and evil, that changes the world outside the narrative by constructing a new textual counter-world. The narrative builds up a group identity that chooses deliberately an alternative position. As encouragement for such alternative position, apocalyptic events guarantee eternal life and community with God for this alternative community.

Three of the articles that were presented on pastoral perspectives on the role and influence of biblical values on social change are taken up in this publication:

- Prof. Dr Fritz W. de Wet spoke about the role of prophetic action in public theology. Public theology should address corruption and encourage sustainable development of the society. He argues that as unabated levels of corruption and its threat to sustainable development are prevalent, a long-awaited reckoning should take place at least within the circles of South African churches from reformed origin. The church should draw from its rich tradition of critical and transformational prophetic involvement in the public space.

- Dr Madelein C. Fourie provided an introductory overview of spirituality in the workplace. She focuses on the individual in the workplace and the meaning of work. She argues that 
organisations of the twenty-first century require from their employees that they not only bring their physical presence and intellect to the work place, but also their spirituality. A growing number of employees are seeking more than mere financial gain in the workplace. Their aim is to create an inspirational and meaningful workspace. Sufficient proof exists that spirituality in the workplace is responsible for creating a new organisational culture in which workers are more content and better achieving.

- The third pastoral perspective comes from Dr Rudy A. Denton. He explores biblical reformational theology as a normative perspective for Christian psychology. The article encourages a holistic sense of cross-disciplinary reflection that enables psychologists to respond to therapeutic situations with faithful, theologically informed practice. He intends to reflect a transversal model of cross-disciplinary dialogue between Christian religion and psychology based on mutuality and respect. Such a dialogue should contribute to serving a healthy society.

I am grateful towards Prof. Dr Jan G. van der Watt, from the Radboud University in the Netherlands and extra-ordinary professor of the NWU, who collaborated with the initiation and planning of this project. I would also like to thank Dr Amanda L. du Plessis for her assistance, contribution and practical arrangements for the conference. 